\title{
Zkušenosti rodičů s inkluzivním vzděláváním
}

\author{
Naděžda \\ Špatenková, ${ }^{a}$ \\ Jana Poláchová \\ Vaštatková, \\ Ivana Olecká, ${ }^{c}$ \\ Jindřiška Riesnarová, ${ }^{d}$
}

\author{
Kontakt \\ a,b,d Univerzita Palackého \\ $v$ Olomouci \\ Filozofická fakulta \\ Kř́žkovského 511/10 \\ 77180 Olomouc \\ anadezda.spatenkova@upol.cz \\ bjana.polachova@upol.cz \\ driesnerovaj@seznam.cz \\ 'Univerzita Tomáše Bati ve Zlíně \\ Fakulta humanitních studií \\ Štefánikova 5670 \\ 76001 Zlín \\ olecka@utb.cz
}

$\triangle$ Korespondence:

nadezda.spatenkova@upol.cz

Copyright $@ 2019$ by the author and publisher, TBU in Zlín.

This work is licensed under the Creative Commons Attribution International License (CC BY).

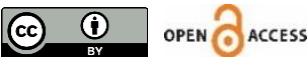

\begin{abstract}
Abstrakt: Inkluzivní vzdělávání je široce diskutovaným tématem, které se řeší ve vztahu $k$ pedagogům, škole jako instituci, $k$ dětem $s$ postižením či směrem $k$ intaktní populaci. Tento text zaměřuje pozornost na rodiče dětí se specifickými vzdělávacími potřebami a design výzkumu směřoval $k$ zodpovězení hlavní výzkumné otázky: „Jaké zkušenosti mají rodiče s inkluzivním vzděláváním?" Kvalitativní výzkumný design směřoval $k$ porozumění toho, jak rodiče "odlišných" dětí vnímají svou specifickou situaci i ve vztahu ke školnímu vzdělávání. Data byla sesbírána narativními rozhovory. Výzkumný soubor tvořilo 9 rodičů dětí se speciálními vzdělávacími potřebami, kteří ve vztahu k inkluzivnímu vzdělávání měli nežrídka i neracionální očekávání. Rodiče nejvíce očekávali vstřícnou, partnerskou komunikaci (se školou jako institucí, ale i s učitelem jejich dítěte) a ačkoliv se střetávali s řadou obtiží na úrovni jednotlivců i systému, přesto stále anticipovali socializaci svého dítěte.
\end{abstract}

Klíčová slova: inkluze, inkluzivní vzdělávání, dítě se zdravotním postižením, rodiče, zkušenost, potřeby rodičů, očekávání rodičů

\section{Parents' experiences with inclusive education}

Abstract: Inclusive education is a widely discussed topic addressed in relation to educators, the school as an institution, children with special needs as well as serving the intact population. This text focuses on the parents of a child with specific educational needs. The main research question of the research design is: "What experience do parents have with inclusive education?" The question is dealt with in relation to the broader framework of school education. Four supplementary research questions were also defined. The data were collected through a series of narrative interviews, with 9 parents of children with special educational needs included in the research group. The parents had often maintained irrational expectations in relation to inclusive school education. The parents most often expected a friendly, partner-based communication (with the school as an institution, but also with the child's teacher), and although they faced a number of difficulties on the level of the individual as well as the system, they still anticipated at least a greater level of socialization of their child.

Keywords: inclusion, inclusive education, child with special educational needs, parents, experience, parents' needs, parents' expectations 


\section{1 Úvod}

Inkluzivní vzdělávání představuje aktuální edukační trend (Bartoňová \& Vítková a kol., 2013; Lazarová a kol., 2015; Švojgrová, 2010). Nebylo tomu tak ale vždy. Řehulka (2013) poukazuje na to, že př́stup k lidem s odlišnostmi měl svůj historický vývoj. Zjednodušeně je možné zaznamenat tyto čtyři etapy: 1. exluze (vylučování), 2. segregace/separace (selektivní př́stup = edukace zvlášt'), 3. integrace (snaha o začlenění osob $\mathrm{s}$ postižením do běžného vzdělávacího proudu) a 4 . inkluze (cílem je různorodost jako norma). Inkluze byla ovšem $v$ České republice ještě poměrně nedávno pojmem zcela neznámým. V zahraničí je tento termín používán již od 60 . let 20. století a podoby $\checkmark$ různých zemích jsou shrnuty různými autory, např. Záhořáková a Kala (2016). Do našeho prostředí proniká až v 90. letech minulého století (Vad'urová, 2009). Předpokládá se, že inkluzivní zaměěení může být nejefektivnějším prostředkem $\mathrm{k}$ eliminaci diskriminujících postojů, vzniku vstřícných komunit, vytváření začleňující společnosti („The Salamanca Statement“, 2019). Inkluzivní př́istup implikuje, že běžné školy by měly vzdělávat všechny děti bez ohledu na jejich fyzické, intelektuální, emocionální, sociální, jazykové nebo jiné podmínky. Pro inkluzivní vzdělávání je nezbytná existence kontinua podpůrných služeb, které budou schopny poskytnout podporu celému spektru speciálních potřeb, jež se vyskytují v každé škole („The Salamanca Statement“, 2019). Jde o přizpůsobení běžné školy a jejich pracovníků potřebám dítěte (Ošlejšková \& Vítková, 2013). Hodkin a Newel (2009) nahlížejí na inkluzi jako na způsob, jak doručit dětem jejich práva - užívají termín child-centered education, který Ize volně přeložit jako způsob vzdělávání, v jehož centru pozornosti stojí dítě samotné. Smyslem inkluze je vytvářet rovné přiležitosti pro vzdělávání všech jakožto jedinečných bytostí a společné vytváření školy jako pospolitosti. Výzkumy ukazují, že dospělí, jejichž postoje jsou více inkluzivní, kladou důraz na výchovnou funkci školy (Greger, Chvál, Walterová, \& Černý, 2009, s. 76). Hlavní zásady inkluzivní pedagogiky je možné vymezit následovně: princip humanizace a demokracie, princip heterogenity; princip spolupráce ve tř́dě i napříc třídami, princip regionalizace, princip otevřenosti vưči okolní komunitě a efektivity, princip individualizace a princip celistvosti (Tannenbergerová, 2016). Inkluzivní vzdělávání se opírá o kreativitu učitele (Booth \& Ainscow, 2007), o využívání diferencovaných výukových metod, pomoc ostatních aktérů inkluzivní pedagogiky (např. psychologa, asistenta pedagoga, výchovného poradce, sociálního pedagoga apod.) i o prípadnou úpravu učiva (Adamus, 2015; Hájková \& Strna dová, 2010; Lang \& Berberichová, 1998; Lechta, 2016; Záhořáková \& Kala, 2016). Vstřícnost vǔči odlišným potřebám a očekáváním a vytváření podnětného edukačního prostředí nejen pro žáky a učitele, ale i pro rodiče a pro jejich zapojování do podpory vyučování je jedním z cílů inkluze (Booth \& Ainscow, 2015; Lukas, 2012).

V České republice vstoupila $v$ roce 2016 v platnost novela školského zákona podporující společné vzdělávání dětí se speciálním vzdělávacími potřebami v běžných školách ${ }^{1}$. Data Ministerstva školství, mládeže a tělovýchovy („Vývojová ročenka školstvi“", 2019) ukazují, jak se tento trend promítá do nárůstu počtu dětí se speciálními vzdělávacími potřebami v běžných školách, a to z celkem 39160 žáků v roce 2011/12 na 53206 ve školním roce 2016/17. Chtějí-li rodiče pro své dítě inkluzivní vzdělávání, mají silnou oporu v legislativě. To ovšem neznamená, že vždy jsou tomuto přistupu nakloněni ředitelé škol či pedagogové na školách. Z rámce českého soukromého práva vyplývá, že za nezletilého žáka jedná ve věci vzdělávání vždy jeho zákonný zástupce, v prípadě tohoto textu rodič, přičemž toto jednání musí být v zájmu dítěte. Školské poradenské zařízení navrhuje nejvhodnější vzdělávací cestu pro žáka se speciálními vzdělávacími potřebami, tj. o samotném způsobu vzdělávání nerozhoduje. Role primárně pečujících osob/rodičů, kteří dítě znají dlouhodobě, rozumí jeho chování a reakcím v různých situacích a mají s dítětem navázaný pevný vztah, je tedy významná a nezastupitelná. Angažovanost rodičů začíná již při samotném hledání vhodné mateřské a/nebo základní školy pro jejich dítě. Rodiče

1 Vyhláška č. 27/2016 Sb., o vzdělávání žáků se speciálními vzdělávacími potřebami a žáků nadaných („Vyhláška“, 2019) stanovuje systém podpưrných opatření prvního až pátého stupně, vymezuje také obsah individuálního vzdělávacího plánu žáka, funkci asistenta pedagoga ve třídě a způsob poskytování podpůrných opatření žákům používajícím jiný komunikační systém než mluvenou řeč. 
vyhledávají informace, navštěvují semináře, přednášky a tato angažovat však nekončí ani v prípadě, kdy dítě začne navštěvovat běžnou školu. Je zcela přirozené, že rodiče, kteří plně pečují o své dítě, chtějí, aby sociální okolí přistupovalo s úctou a zájmem nejen k jejich potomkovi, ale i k nim samotným. Zároveň je zřejmé, že zcela jistě ne všichni rodiče dětí se specifickými potřebami chtějí či mohou věnovat tolik úsilí a energie do školního vzdělávání. Jak uvádí Hájková a Strnadová (2010, s. 70) je odlišnost př́stupu dána mimo jiné i diagnózou dítěte, jeho věkem a místem, kde je vzděláváno. Autoři v rámci vlastního výzkumu zjistili, že rodiče dětí s Downovým syndromem bývají velkými zastánci inkluze, zatímco rodiče dětí s poruchami autistického spektra se klonili jen $\mathrm{k}$ částečné inkluzi. Rodiče malých dětí a dětí vzdělávajících se v běžných školách měli k inkluzi pozitivnější postoj, než tomu bylo u rodičů starších dětí a dětí navštěvujících školu speciální. Kunhartová, Potměšil a Potměšilová (2017) konstatují, že učitel ani speciální pedagog, natož vedení školy nemohou vědět, co pro daného rodiče jeho situace (skutečnost, že mají odlišné dítě) konkrétně znamená.

Požadavky rodičů dětí v inkluzivním vzdělávání obvykle souvisí s jejich obavami (Dobiášová, 2018; Hájková \& Strnadová, 2010) a mohou se týkat např. bezpečnosti dítěte; sociální izolace dítěte; postojů ostatních žáků vůči jejich dítěti; kvalitě vzdělávacího programu dané školy, osobnosti učitele; dostupnosti školy z hlediska dopravy. Lang a Berberichová (1998) uvádějí, že rodiče těchto dětí mohou mít potřebu častějšího a intenzivnějšího kontaktu s učitelem svého dítěte a od školy (nejen ze strany učitelư, ale též vedení školy) potřebují především podporu a porozumění. Také jiní autoři (Vágnerová, Strnadová, \& Krejčová, 2009) upozorňují na to, že rodiče dětí se speciálními vzdělávacími potřebami neposuzují u učitelů pouze jejich pedagogickou práci či přistup $k$ dítěti, ale je pro ně důležité i to, jaký postoj zaujímá učitel vưči nim samotným. Rodiče si přejí, aby je učitel považoval za svého rovnocenného partnera. Pokud však učitel zaujímá vůči těmto rodičům nadřazený postoj a činí vzájemný vztah asymetrickým, může tato nerovnováha sil rodiče znepokojovat, znejištovat apod. Michalík (2012) proto zdůrazňuje, že by $v$ žádném případě mezi oběma stranami ve vzájemné komunikaci a interakci neměla převládat nedůvěra či mocenské řešení dílčích situací. Doposud realizované výzkumy inkluzivního vzdělávání v ČR však akcentují pohled či postoje učitelů, resp. ředitelů škol regionálního školství. Předložený text reflektuje inkluzivní vzdělávání v základní škole optikou rodičů inkludovaných dětí.

\section{Soubor a metody}

Inkluze $v$ souladu $s$ novelou školského zákona podporující společné vzdělávání dětí se speciálním vzdělávacími potřebami v běžných školách je v českém kontextu aplikována teprve čtvrtým rokem. Zájem výzkumníků se tak logicky soustředí zejména na analýzy situace ve školách (Moree, 2018; Vorlíček, 2018). V našem výzkumu se ale pozornost upřela na jiné aktéry inkluzivního vzdělávání. Subjekty výzkumu jsou rodiče, jejichž děti zažily „první vlnu“ inkluze bezprostředně poté, co zmiňovaná novela vešla $v$ platnost. $V$ rámci prezentované pilotní studie bylo provedeno devět rozhovorů se záměrem porozumět zkušenostem rodičů se vzděláváním svých dětí v první vlně inkluze. Byly zvoleny tři výzkumné otázky: 1 . Z jakých důvodů se rodiče rozhodli pro inkluzivní vzdělávání; 2 . Jak vnímají průběh inkluzivního vzdělávání; 3. Jaké strategie volí ke zvládání situací vyplývajících z inkluzivního vzdělávání.

Pro vstup do terénu byla zvolena technika polostrukturovaného rozhovoru. S ohledem na výzkumný problém a cíl výzkumu byl zvolen kvalitativní výzkumný design. Vzhledem $\mathrm{k}$ tomu, že reakce rodičů se odvijí od jejich adaptace na aktuální životní situaci, zaměǐl se výzkumný rozhovor nejprve na tuto skutečnost. Rodiče byli požádáni, aby vyprávění začali širším vyprávěním o podmínkách, ve kterých spolu s dítětem žijí, o své životní situaci. Koncept životní situace je sice využíván především v sociální práci, inspirativní může však být i pro sociální pedagogiku. Jedinec a sociální prostředí jsou ve vzájemné interakci, jedinec není izolovaný od svého prostředí. Podle Barlett (1970), autorky tohoto konceptu, vytváří sociální fungování dva segmenty - životní úkoly a jejich zvládání. Životní úkoly jsou požadavky, které jsou na jedince kladeny prostřednictvím různých životních situací. Zvládání představuje určitý 
stupeň schopnosti jedince vypořádat se se životními situacemi, které je možné chápat jako společenské úkoly, životní problémy či životní situace. Životní situaci pak jedinec vnímá jako tlak sociálního prostředí. Citovaná autorka vymezuje tři atributy životní situace a to: 1 . schopnost jedince zvládat životní situaci, 2. očekávání a požadavky prostředí a 3. podpora prostředí. Sociální pedagogika se zabývá mimo jiné právě tématy sociální rizikové životní situace, problematikou prostředí, socializací a výchovou, právy dětí apod. (Bendl, 2016; Knotová a kol., 2014; Kraus, 2014; Lorenzová, 2001). Všechny tyto aspekty byly reflektovány i v rámci prezentovaného výzkumu. Pro účely předkládaného výzkumu bylo za životní situaci chápáno porozumění odlišnosti dítěte a $\mathrm{s}$ tím související specifické vzdělávací potřeby dětí, ale i jejich rodičũ. Posléze bylo explorováno rozhodování rodičů pro inkluzivní vzdělávání, včetně volby konkrétní školy a následně byla reflektována dosavadní zkušenost rodičů s tímto vzděláváním, přičemž zkušenost byla vymezena jako „to, co bylo prožito a uchováno v paměti jedince" (Hartl \& Hartlová, 2010). Jedincem se tak v kontextu tohoto textu rozumí rodič dítěte a zkušeností jeho subjektivní prožitek vyrovnávání se se specifiky svého dítěte, včetně okolností souvisejících se vzděláváním dítěte. Sběr dat proběhl v první polovině školního roku 2017/2018.

Výzkumný soubor byl konstruován metodou sněhové koule. Nejprve byla se žádostí o spolupráci oslovena škola, která na svých webových stránkách deklaruje proinkluzivní zaměření. Škola souhlasila s tím, že kontaktuje rodiče dětí se specifickými vzdělávacími potřebami a předá jim informace o výzkumu s prosbou o spolupráci. Na nabídku pozitivně zareagovali dva rodiče z oslovené školy. Skrze tyto rodiče byli následně vybráni další komunikační partneři. Výzkumný soubor byl tvořen osmi ženami (matkami) a jedním mužem (otcem). Věk participantů se pohyboval $v$ rozmezí 30 až 46 let. Specifické údaje o participantech shrnuje dále uvedená Tabulka 1. Rozhovory byly vedeny vždy pouze s jedním z rodičovského páru.

Tabulka 1

Charakteristiky komunikačnich partnerů

\begin{tabular}{lllllll}
\hline $\begin{array}{l}\text { Komunikační } \\
\text { partner }\end{array}$ & Pohlaví & Věk & Vzdělání & Věk dítěte & Specifika dítěte & $\begin{array}{l}\text { Úplná } \\
\text { rodina }\end{array}$ \\
\hline KP1 & Žena & 41 let & VŠ & 10 let & Vývojová dysfázie & $\mathrm{Ne}$ \\
KP2 & Žena & 42 let & SŠ & 12 let & Atypický autismus & $\mathrm{Ne}$ \\
KP3 & Žena & 43 let & SOU & 12 let & ADHD & $\mathrm{Ne}$ \\
KP4 & Žena & 44 let & VŠ & 12 let & Atypický autismus & $\mathrm{Ne}$ \\
KP5 & Žena & 44 let & VŠ & 16 let & Vysokofunkční autismus & Ano \\
KP6 & Žena & 36 let & SOU & 8 let & Porucha pozornosti se & $\mathrm{Ne}$ \\
& & & & & známkami ADHD, poruchy & \\
& & & & & učení & \\
KP7 & Žena & 41 let & VŠ & 11 let & Ochrnutí dolních končetin & $\mathrm{Ne}$ \\
KP8 & Žena & 30 let & SŠ & 10 let & Downův syndrom & $\mathrm{Ne}$ \\
KP9 & Muž & 32 let & SOU & 8 let & ADHD, autismus & $\mathrm{Ne}$ \\
\hline
\end{tabular}

Rozhovory probíhaly v klidném, nerušeném prostředí. Vždy se jednalo o domácnost komunikačních partnerů. Před započetím výzkumu byli komunikační partneři seznámeni s cílem výzkumu a průběhem realizace rozhovorů. Jednotlivé rozhovory byly zaznamenány na diktafon, byly přepsány a zakódovány otevřeným kódováním (jednotlivé fragmenty vět, případně i větné celky, byly tříděny dle obdobného významu, vytvářeny byly kategorie, rozvíjeny jejich vlastnosti). Proces sběru dat byl pečlivě zaznamenáván do terénního deníku. Poznámky v terénním deníku následně posloužily při analýze dat. Analýza probíhala průběžně po každém rozhovoru. Díky tomu bylo možné výsledky základní analýzy dat využít v rámci příprav na další rozhovor. Abstrahované kategorie získané při první fázi kódování byly opakovaně evidovány. $V$ průběhu analýzy bylo třeba se $k$ původním rozhovorům opakovaně navracet a identifikované kódy znovu ověřovat a revidovat vzniklé kategorie. 


\section{Výsledky}

Při otevřeném kódování byly nalezeny celkem tři kategorie, pomocí kterých Ize porozumět zkušenostem rodičů s inkluzivním vzděláváním v kontextu vývoje jejich životní situace. Následující text tuto linearitu respektuje, proto je nejprve zařazena podkapitola Inkluze jako projev touhy po normalitě (vysvětlující okolnosti rozhodování rodičů pro inkluzivní vzdělávání), poté je představena jejich zkušenost pomocí kategorie Dítě mezi světy a $v$ závěrečné podkapitole je nejprve identifikována náhoda jako faktor přispívající k úspěšné inkluzi a poté dvě strategie, které rodiče používají k řešení dopadů inkluzivního vzdělávání.

\subsection{Inkluze jako projev touhy po normalitě}

První kategorie objasňuje okolnosti rozhodování rodičů pro inkluzivní vzdělávání a je sycena třemi kódy: Strach ze stigmatizace, Možnost vyrůstat v normálním světě a Podpora nezávislosti dítěte na rodičích.

Volba způsobu vzdělávání a i výběr konkrétní školy nebyl pro komunikační partnery jednoduchý, rodiče dlouze zvažovali nejen obsah a kvalitu předávaných informací v rámci vzdělávání, ale i další okolnosti, např. praktické: „Družina ve speciální škole byla otevřena velice krátce.“ (KP2). „Speciální škola není nikde v mistě bydliště" (KP4). V rozhovorech artikulovali strach ze stigmatizace dítěte, které by mělo být vzděláváno ve „skleníku“ speciální školy. „Moje děcko se nebude vzdělávat s těma druhýma, dyt' na tom není tak hrozně. Jakože není přece mentál. Pardon za to slovo, to já nechtěl" (KP9). Představy komunikačních partnerů o speciální škole vycházely především ze stereotypizovaných představ, které vrhají negativní světlo nejen na tyto školy, ale i na rodiče dětí, které děti do těchto škol umistují: „V těch speciálních školách jsou děti, kterým se třeba rodiče i tolik nevěnuji, neřeší jejich problémy, a tudiž jsou v těch školách" (KP3).

Zařadit dítě do běžné školy považovali komunikační partneři za přirozenou a jedinou možnost pro to, aby dítě mělo možnost vyrůstat v normálním světě: "Dítě se naučí mnohem lépe komunikovat s běžnými dětmi.“ (KP2). „Aby byla zařazená do běžného života.“ (KP3). Očekávání od vzdělávání dítěte $\checkmark$ běžné základní škole u jednotlivých komunikačních partnerů tak směřovala i k podpoře nezávislosti dítěte na rodičích: „Aby pak děcko v životě nebylo prekvapeno“ (KP1), ",Celej život na mně přece nemůže bejt závislej!“ (KP9) a ke kontaktu s běžnou společností ve škole: „Chtěli jsme, aby naše holčička byla $v$ co nejširším kontaktu s běžnými dětmi," (KP2) i mimo ni „A také má tady v okolí kamarády už od školky a následně i ve třídě a setkává se s nimi i mimo vyučování. A navíc ji tyto zdravé děti motivuji $k$ tomu, aby se více učila, aby se chovala jako ony, přebírá zdravé vzorce chování a tím zdravé myslím $v$ uvozovkách" (KP4).

\subsection{Dítě mezi světy}

Zkušenosti s průběhem inkluzivního vzděláváním vystihuje kategorie, kterou Ize přiblížit čtyřmi kódy: Koexistence dětských světů, Nespravedlivý přístup učitelů k dítěti, Absence partnerství dospělých a Dítě jako závaží.

Téma začleňování dítěte do kolektivu třídy bylo z pohledu rodičů významné pro dítě i pro rodiče jakožto proces, který nutně nevedl k plnému začlenění, ale spiše ke koexistenci dětských světů. Se začleněním pomáhali zejména spolužáci, roli však hraje i osobnost samotného dítěte "S dětmi je $v$ pohodě, ale to má dcera obecně, že má svůj svět, že si ráda sama tvoři něco svého. Ona část času tráví $v$ kolektivu a část času tráví sama, nevidím tam žádný problém“ (KP6). „Náš syn stojí mimo kolektiv, neumí se sám začlenit. Asistent ho $k$ tomu nutil, ale nejde to. To si prostě nevynutíte" (KP4). Pokud nevolili učitelé vhodný př́stup $\mathrm{k}$ dítěti, nepomáhají mu v začlenění do kolektivu, je tak opět na rodiči, aby usiloval o nápravu: „Nejdřive učitelé moc dceru nebrali, ale po tom, co byla ve škole inspekce a zjistila pochybenív jejich práci a v přistupu, a také se změnou třídní učitelky, je dcera ve škole v normálním postaveni" (KP4). 
Při formulaci zkušeností $s$ vzdělávání v běžné škole tematizovali rodiče absenci respektování specifik dítěte projevující se $v$ absenci individuálního prístupu učitelů vůči jejich dítěti vyústúující v pocit nespravedlnosti. „Potřebuje individuální př́stup a pochopení, pozitivní motivaci a ocenění jejich snahy, ale taky jasně daná a pochopitelná pravidla“ (KP4). „Žák s inkluzí potřebuje na vše mnohem více času, ale učitelé nemají na nic čas" (KP5). „Dcera dělá všechno, co ostatní děti, jedině co nedělá, jsou slovní úlohy, ale na známkování se to neprojeví, nedostane koule" (KP6). Rodiče se tak dostávají do dilematické situace. Na jedné straně touží socializovat dítě v podmínkách běžné školy, aby jejich dítě nebylo vyčleněno, na straně druhé si stěžují, že jejich dítě je srovnáváno s ostatními žáky a tento fakt považují za nespravedlivý. Nespravedlnost se projevila i tím, že se dítě ocitá mezi "systémy“ (uvnitř školy, mezi školou a poradenským pracovištěm a mezi školou a rodinou), které spolu dostatečně nespolupracovaly, čas dítěti plynul a rodiče museli vynaložit velké úsilí, aby dosáhli toho, na co má dítě právo: „Jenže škola doporučení nedodržovala a já si na to v poradně stěžovala, dcera byla přetižená, začaly velké problémy a poradna mi řekla, že to oni nezajištují, že se jich to netýká a že si to musím zajistit sama. Nic nepomáhalo, škola se dokonce obrátila na OSPOD, a mně nezbylo nic jiného, než se obrátit na Českou školní inspekci. Ta zjistila velká pochybení ze strany poradny, ostatně i ze strany školy, a doporučili mně, abych změnila poradnu. Tak jsem tak učinila a v další poradně, tedy speciálně pedagogickém centru, zjistili další diagnózy dcery a pohlídali správné nastavení učiva a podpưrných prostředků ve škole" (KP4).

Komunikační partneři tematizovali i absenci partnerství mezi dospělými (rodiče s pedagogy a s dalšími experty např. z poradenských pracovišt'): „Já musím být ta, co škemrá, a oni mi ř́kají, že mohou, ale nemusí mi vyjít vstřic" (KP7). Učitelé byli podle komunikačních partnerů většinou neangažování, a bylo na rodičích případné problémové situace řešit, přičemž se de facto jednalo „o boj“, kdy se škola stavěla proti rodičům a jejich požadavkům týkajících se např. dodržování doporučení ze strany školského poradenského zařízení. „S IVP mám zkušenost asi takovou, že škola si jej nějak zpracuje, vezme si ze zprávy poradny jen to, co chce a předloží mi to k podpisu. Když mám k plánu připomínky, že neodpovídá doporučení a ani realitě, tak mi dělá škola velké problémy" (KP4)Komunikačním partnerům chyběl zájem pedagogů o jejich situaci, vzdělávací potřeby dítěte, necítili se dostatečně respektováni jako partneři. Komunikačním partnerům chyběl zájem pedagogů o jejich situaci, vzdělávací potřeby dítěte, nebyli podle komunikačních partnerů bráni jako partneři školy, pedagogů, ale spiše jako někdo, kdo je problémový a ztěžuje jejich práci: „Vưbec nic mi neřekli o tom, že múže mít asistenta. A jaký má $L^{* *}$ šance. Prostě to bylo ze začátku hodně zlý a já jsem se cítil hodně špatně" (KP9). „Škola neposkytuje žádné poradenství, nehovořís rodiči o tom, jak probíhá inkluzivní vzdělávání ditěte ve škole, co je třeba vylepšit nebo čeho se vyvarovat, nebo jak navzájem spolupracovat, aby se dítěti ve škole dařilo" (KP2).

Rodiče požadavky ze strany školy je nezř́dka zaskočily: „Překvapilo nás, že po nás chtěli zajistit asistenta pedagoga" (KP2). Požadavky školy byly formulovány jako př́kazy, byly označovány za povinnost rodičů. Obavy z nesplnění požadavků školy projevilo více komunikačních partnerů, stejně jako se setkali sodmítavým př́stupem nebo jim přímo bylo doporučeno přehlášení dítěte na jinou školu: „Úplně první kontakt nebyl nějak extra takový, jaký bych si predstavovala, snažili se mě přesvědčit o tom, abych dceru dala jinam, snažila jsem se je přesvědčit, aby dceru vzali. Myslím, že jejich hodnocení bylo velmi zaujaté z důvodu toho, že neměli takové informace jako já, neznali dceru osobně a mysleli si, že vše dopadne špatně" (KP8). Komunikační partneři ze strany školy slyšeli, že pro jejich dítě není vhodná, vhodnější je škola speciální: „Vypadalo to, jakože ho chcou dostat pryč, aby s ním neměli tolik práce a aby se nesnižovala ta dobrá jakože pověst školy, že tam mají děcka dobrý známky" (KP9). Jejich dítě se tak stávalo pro školu prítěží.

\subsection{Náhoda jako faktor úspěšné inkluze}

Úspěch inkluzivního vzdělávání podle komunikačních partnerů závisí z velké části na lidech, na zájmu a ochotě jednotlivých konkrétních pracovníků školy a školských poradenských zařízení, cílené komunikaci a vstřícné spolupráci. Značně se tak projevoval vliv náhody - rodič mohl mít „štěstí“ nebo 
„smůlu“ v tom, s kým jednal - tedy zda se jednalo o pro-inkluzivního nebo proti-inkluzivního pracovníka (učitele, speciálního pedagoga v SPC, ředitele školy): „Zjistila jsem, že dobře provedená inkluze je opravdu jen a jen o lidech a jejich př́stupu $k$ těmto dětem a jejich pochopeni" (KP4). Do pracovníků školských poradenských zařízení vkládali své naděje, a to i v případě řešení svých problémů se školou: „Výborná zkušenost, nevýhodou jsou dlouhé čekací doby a málo častý kontakt" (KP5). „V té poradně byly úpIně zlaté ženské. Klidně školy objiždějí a dovysvětlí, co to dítě konkrétně má mit, a to jsou pritom mladý holky, nevím ani třiadvacet let, fakt výborný" (KP6) „Zkušenosti s PPP a SPC mám celkem dobré, i diky nim je dcera v klasické základní škole" (KP8). Podobně měli většinou všichni komunikační partneři dobrou zkušenost s asistenty pedagoga: „Asistentka je opravdu výborná, funguje s dcerou tak, jak má. Ty asistenty dělají lidi, co je to baví, protože ty platy nejsou nic moc, ... od toho se to všechno odviji" (KP6), přičemž právě asistent pedagoga je podle komunikačních partnerů velmi důležitý, je-li tento podpůrný prostředek dítěti přiznán. Komunikační partneři v našem výzkumu měli dojem, že učitelé asistenty pedagoga nevnímají jako své spolupracovníky, ale spíše jako někoho, koho si má rodič pro své dítě zajistit sám. Odmítavý př́stup pracovníků školy tak vedl u rodičů k prožívání silných negativních emocí, což bylo způsobeno častým zdůrazňováním učitelů, že je jejich dítě jiné, pro školu problémové, do jejich školy nepatří. Mezi rodiči a školou tak často vznikaly problémy, které škola nebyla ochotná řešit, odpovědnost byla svalována na rodiče.

Při hledání strategií, které rodiče používají pro zvládání okolností vyplývajících z inkluzivního vzdělávání, se jako dominující ukazuje laická podpora. Rodiče naráželi na problém chybějících informací. "Já informace neměla žádný. Tenkrát to nebylo" (KP3), „Jen kamarádka mi ř́kala, že její autistický syn má asistenta" (KP4). Potřebné informace související s inkluzivním vzděláváním získávali postupně, většinou až poté, co čelili obtížím. To jim přinášelo značný stres, který se však komunikačním partnerům podařilo překonat, především mobilizací svých zdrojů a aktivním jednáním, i když se jednalo o dlouhodobý a pro ně často vyčerpávající proces. „Zejména chybí informace o tom, jak s takovým dítětem pracovat. Odborníci si většinou jen zapiší, co dítě dělá nebo nedělá, ale rodičům neporadí, jak s takovým dítětem pracovat a jak ho rozvijet" (KP1). Komunikačním partnerům chyběly zejména informace o možnostech, které má škola, ale i o možnostech, které má rodič. „Škola neposkytuje žádné poradenství, nehovořís rodiči o tom, jak probíhá inkluzivní vzdělávání našeho dítěte ve škole, co je třeba vylepšit nebo čeho se vyvarovat, nebo jak navzájem spolupracovat, aby se dítěti ve škole dařilo" (KP2). Rodič tak nevěděl, na koho se má obrátit se žádostí o pomoc, jaké doklady je zapotřebí $k$ tomu, aby dítěti byly ve škole poskytnuty potřebné podpưrné prostředky apod. Zároveň žádný z komunikačních partnerů neuváděl, že by v souvislosti se školním vzděláváním vyhledal další odbornou pomoc. Důvodem byly i předchozí negativní zkušenosti, vnímaná podpora ze strany tzv. pomáhajících profesionálů tak byla v našem výzkumu většinou nízká: „Odmala jsme upozorňovali každého lékaře, psychologa, imunologa, v pedagogicko-psychologické poradně, že má dítě specifické pohyby ručičkami, a nikdo si toho nevšímal a nekomentoval. Až nyní, po tolika letech jsme se dověděli, že je to projev autisty" (KP2). Pokud rodiče získali informace týkající se inkluzivního vzdělávání, činili tak na internetu: „Podívala jsem se na webové stránky školy" Vyhledávání odborné pomoci souviselo především s problémy dítěte - potřeba psychologického či psychiatrického vyšetření dítěte, kontakt se speciálními pedagogy z SPC atd. Napomáhaly též poznatky získané od jiných „laikư“, ze sociálního okolí rodičů: „Ona mi ta známá pak poradila, že její dcera je na normální škole, už druhej stupeň a má svýho pomocníka, asistenta ve škole, kterej s ní sedí a pomáhá jí v učivu." (KP9). Z rozhovorů významným způsobem vyvstala potřeba opory v rodině. Ta byla silně akcentována především v situaci, kdy se život rodiny zásadně změnil (např. problémy v soužití, odchod druhého rodiče z rodiny apod.). Komunikační partneři $v$ našem výzkumu převážně zůstali na výchovu dítěte $s$ postižením sami. Druhý rodič se $s$ dítětem stýká jen sporadicky, maximálně několik dní v měsíci. Komunikační partneři uvádějí, že na péči o dítě se často a intenzivně podílejí prarodiče dítěte. 


\section{Diskuse}

Zkušenost rodičů s inkluzivním vzděláváním svých dětí se odvíjela zejména od toho, jaká byla jejich původní očekávání, a to zejména očekávání vưči škole, ale též od toho, jakou pomoc rodiče dítěte obdrželi (jaká byla kvalita i kvantita této pomoci) a jaký byl př́stup odborníků (lékařů, učitelů, pracovníků školského poradenského zařízení apod.) k rodičům. Neméně významná je pochopitelně i odlišnost dítěte, tedy např. jeho specifické vzdělávací potřeby a průběh procesu inkluze dítěte. Roli hraje i to, kdy a jak rodiče přijali specifika svého dítěte, kdy někteří je zjistili již v raném věku a jiní až po vstupu potomka na základní školu, poté, co se změnil styl vyučování a nároky kladené školou na dítě. Rodiče museli řešit mnoho obtí̌ných situací (odmítání dítěte školou, neochota školy naplňovat požadavky dané legislativou, nedostatečná spolupráce mezi školou a školským poradenským zařízením apod.). Průběh inkluze rozhodně neprobíhal podle představ rodičů, ani dle potřeb dítěte, jak ukazují jejich výpovědi. $V$ této souvislosti je třeba připomenout, že našimi komunikačními partnery byli rodiče dětí z „první vlny“ inkluze (rozhovory s komunikačními partnery probíhaly ve školním roce 2017/2018). Je zřejmé, že inkluzivní vzdělávání je pro české školství zásadní změnou, a každé zavádění změn je doprovázeno obtížemi. Nicméně popisované skutečnosti měly následně vliv nejen na emotivitu a reaktivitu rodičů, ale $\mathrm{i}$ na socializaci dítěte, které nebylo vždy dobře podpořeno učitelem $\checkmark$ začleňování do kolektivu, bylo přetěžováno (domácí úkoly prováděné několik hodin denně i přes odlišné doporučení školského poradenského zařízení) a pochopitelně narůstal i požadavek na zvládání dané životní situace rodiči. Inkluze $v$ našem výzkumném vzorku tedy rozhodně neprobíhala bez problémů, rodiče "sváděli boj" se školou, se systémem, slidmi, od kterých měli obdržet pomoc a podporu (např. pediatři, učitelé, pracovníci v SPC apod.). Přes veškeré problémy, kterým komunikační partneři v našem výzkumu čelili, vnímají ve svém důsledku inkluzi jako pozitivní a věří, že inkluze je (nejen) pro jejich dítě obohacující. To, že inkluze neprobíhala podle jejich očekávání, přinášelo komunikačním partnerům zklamání, rozčarování, vyčerpaní, psychické i časové přetížení.

Bazalová (2012) vidí hlavní faktory selhávání inkluze především v nedostatku finančních prostředků, v nouzi o materiální vybavení, v personálních záležitostech, v postojích pedagogů a ostatních žáků vyplývajících z nedostatečné informovanosti a ve slabé podpoře ze strany školských poradenských zařizení. Naši komunikační partneři ale jednoznačně zdůrazňovali, že „je to především o konkrétních lidech". Obtíze s inkluzivním vzděláváním nepřisuzovali systému, filozofii inkluze, ale pouze selhání lidského faktoru (jednotlivých učitelů, ředitelů, zřizovatelů školy). Aktivity pracovníků školských poradenských zařízení a asistentů pedagoga hodnotili pozitivněji, ale problém spatřovali v nepřipravenosti systému: v nedostatečném provazování různých světů.

Překládaný výzkum potvrdil, že se rodiče považují za „experty na svoji životní situaci“, „experty na své dítě" a předpokládají, že je takto bude vnímat i škola, resp. učitel jejich dítěte. $V$ této souvislosti vystupuje do popředí význam úzké spolupráce učitele s rodiči žáka, protože rodiče dětí v inkluzivním vzdělávání bývají zpravidla velmi angažovaní (Lang \& Berberichová, 1998) a mohou být učiteli nápomocni např. v efektivním přístupu k dítěti (Ošlejšková \& Vítková, 2013). Michalík (2012) je toho názoru, že rodiče dětí v inkluzivním vzdělávání potřebují především individuální prístup - $k$ dítěti, jim samotným, celé rodině, avšak tento požadavek není podle autora v praxi vždy naplňován. Uvedený závěr potvrzuje i výzkum prezentovaný v tomto článku.

\section{Závěr}

Záměrem textu bylo identifikovat zkušenosti rodičů s inkluzivním vzděláváním. Lze říci, že komunikační partneři chápou inkluzi jako prínosnou pro své dítě ve snaze začlenit se do běžné společnosti a přes řadu obtíží, se kterými se setkávají, tento názor nemění a své původní rozhodnutí pro inkluzivní vzdělávání nerevidují. Pro úspěšnou inkluzi je klíčová především efektivní komunikace a spolupráce jednotlivých aktérů inkluze a předávání potřebných informací, což vytváŕí značný prostor pro uplatnění sociálních pedagogů. Tito mohou facilitovat vytvoření vhodného sociálního prostředí pro inkluzi dětí 
se speciálními vzdělávacími potřebami, saturovat potřebu rodičů ohledně komunikace, sdílení a potřeby informací. Naši komunikační partneři získávali potřebné informace zpravidla z laických zdrojů, informace o inkluzivním vzdělávání by ovšem měli získávat systematičtěji a cíleněji. Experti (at' už učitelé nebo další poradenští odborníci) mohou také pomoci rodičům odlišných dětí „vyladit" jejich představy a očekávání od inkluze a uvést je do souladu s realitou, pokud budou mezi sebou spolupracovat a vzájemně na své poznatky $v$ další práci navazovat. Rodiče inkludovaných dětí deklarovali, že by přivítali možnost to s někým kompetentním probrat, př́padně si nechat některé věci vysvětlit. Tímto „kompetentním odborníkem" může být i sociální pedagog. Životní situace rodičů inkludovaných dětí není jednoduchá a zpětně si uvědomují, že pokud by existovala nějaká konkrétní artikulovaná nabídka doprovázení či poradenství, rádi by jí využili, protože péče o odlišné dítě, včetně procesu

Potíže v komunikaci, chybějící informace a nízká ochota ke spolupráci dospělých aktérů tvoří dle dotazovaných rodičů základní bariéru skutečné inkluze jejich dětí. Facilitace tvorby vhodného sociálního prostředí a saturace potřeb komunikace a sdílení informací se tak na cestě za naplněním vizí inkluzivního školního vzdělávání jeví jako klíčová. jeho začleňování do běžné školy, byla většinou velmi emočně náročná. Vůči psychologickému poradenství jsou komunikační partneři ovšem negativně zaujatí: „Co jsem nějaký blázen, abych chodil někam k psychologovi?“ (KP2). Nicméně podpora jiných pomáhajících profesionálů je pro ně přijatelná. Právě proto by se nabídka intervence a podpory ze strany sociálního pedagoga mohla v tomto ohledu jevit jako vhodná alternativa. Tato podpora by však neměla být směrována pouze $k$ dítěti, nýbrž také $k$ rodičům a dalším aktérům inkluzivního vzdělávání s cílem vytvořit dítěti vstřícné prostředí pro rozvoj a sociální začlenění.

\section{Literatura}

Adamus, P. (2015). Metodika hodnocení kvality inkluzivní školy. Opava: Slezská univerzita.

Bartoňová, M., \& Vítková, M. (2013). Inkluze ve vzdělávaní - Vize a realita v podmínkách české školy. In P. Franiok \& R. Kovářová (Eds.), Speciální pedagogika nejen v inkluzivním vzdělávání. Sborník príspěvků z konference s mezinárodní účastí (s. 21-35). Ostrava: Ostravská univerzita v Ostravě.

Bazalová, B. (2012). Poruchy autistického spektra v kontextu české psychopedie. Brno: Masarykova univerzita.

Bendl, S. (2016). Základy sociální pedagogiky. Praha: Univerzita Karlova v Praze.

Booth, T., \& Ainscow, M. (2015, červenec 20). Index for inclusion developing learning and participation in schools. CSIE. Dostupné z https://www.eenet.org.uk/resources/docs/Index\%20English.pdf

Dobiášová, P. (2018, řijen 1). Analýza potřeb rodiny se zaměřením na potréeby dětí, mládeže a rodiny s dětmi se zdravotním postižením. Závěrečná zpráva ze sociologického šetření. Dostupné $z$ http://m.mesto-podebrady.cz/assets/File.ashx?id_org=12349\&id_dokumenty=16533

Greger, D., Chvál, M., Walterová, E., \& Černý, K. (2009). Názory českých rodičů a veřejnosti na časné rozdělování žáků. Orbis scholae, 3(3), 51-78. Dostupné z https://www.researchgate.net/profile/Martin_Chval/publication/309675779_Nazory_ceskych _rodicu_a_verejnosti_na_casne_rozdelovani_zaku/links/581cc31e08ae12715af209de/Nazoryceskych-rodicu-a-verejnosti-na-casne-rozdelovani-zaku.pdf

Hájková, V., \& Strnadová, I. (2010). Inkluzivní vzdělávání. Praha: Grada.

Hartl, P., \& Hartlová, H. (2010). Velký psychologický slovník. Praha: Portál. 
Hodkin, R., \& Newel, P. (2009, duben 3). Implementation handbook for the convention on the rights of the child. UNICEF. Dostupné z https://www.unicef.org/ecuador/Implementation Handbook_for_the_Convention_on_the_Rights_of_the_Child.pdf

Knotová, D. a kol. (2014). Úvod do sociální pedagogiky. Brno: Masarykova univerzita.

Kraus, B. (2014). Základy sociální pedagogiky. Praha: Portál.

Kunhartová, M., Potměšil, M., \& Potměšilová, P. (2017). Náročné otcovství. Být otcem dítěte s postižením. Praha: Karolinum.

Lang, G., \& Berberichová, CH. (1998). Každé dítě potřebuje speciální přistup: vytváření integrovaných a inkluzivních tříd. Praha: Portál.

Lazarová, B., Opařilová, D., Ošlejšková, H., Pančocha, K., Pipeková, J., Pol, M., ... Záměčníková, D. (2015). Inkluze ve škole a ve společnosti jako interdisciplinární téma. Brno: Masarykova univerzita.

Lechta, V. (Ed.). (2016). Inkluzivní pedagogika. Praha: Portál.

Lorenzová, J. (2001). Sociální pedagogika jako pomáhající disciplína. Pedagogika, 3(51), 292-298. Dostupné z http://pages.pedf.cuni.cz/pedagogika/?p=2201\&lang=cs

Lukas, J. (2012). Připravenost školy k inkluzivnímu vzdělávání. Praha: Národní ústav pro vzdělávání.

Michalík, J. (2012). Rodiče a dítě se zdravotním postižením (nejen) na základní škole. Pardubice: Studio Press.

Moree, D. (2018). Systém v ne-systému aneb inkluze rok poté. Praha: Nadace Open Society Fund.

Ošlejšková, H., \& Vítková, M. (2013). Východiska, podmínky a strategie ve vzdělávání žáků s těžkým postižením na základní škole speciální. Brno: Masarykova univerzita.

Řehulka, E. (2013). Psychologické a psychohygienické otázky vzdělávání žáků se zdravotním postižením z pohledu inkluze. In H. Ošlejšková \& M. Vítková, Východiska, podmínky a strategie ve vzdělávání žákủ s těžkým postižením na základní škole speciální (s. 39-54). Brno: Masarykova univerzita.

Švojgrová, P. (2010). Analýza názorů na poskytování poradenských služeb žákům s narušenou komunikační schopností. In M. Bartoňová \& M. Vítková a kol, Inkluzivní vzdělávání v podmínkách současné školy (s. 135-142). Brno: Masarykova univerzita.

Tannenbergerová, M. (2016). Průvodce školní inkluzí aneb jak vypadá kvalitní základní škola současnosti? Praha: Wolters Kluwer.

The Salamanca Statement and Framework for Action on Special Needs Education. (2019, duben 30). UNESCO. Dostupné z http://unesco.org/education/pdf/SALAMA_E.PDF

Vad'urová, H. (2009). Sociální podpora a komunikace jako významné faktory zvládání zátěže u pečovatelů o děti se závažným onemocněním. In M. Bartoňová \& M. Vítková a kol., Vzdělávání žáků se speciálními vzdělávacími potrebami III. (s. 201-210). Brno: Masarykova univerzita.

Vágnerová, M., Strnadová, I., \& Krejčová, L. (2009). Náročné mateřství. Být matkou postiženého dítěte. Praha, Karolinum.

Vorlíček, R. (2018). „Naše učitelka nás naučila vytvářet skupinky rovnoměrně “: sociální inkluze v základní škole. Český lid, 105(1), 45-65. https://doi.org/10.21104/CL.2018.1.03.

Vyhláška č. 27/2016 Sb. Vyhláška o vzdělávání žáků se speciálními vzdělávacími potřebami a žáků nadaných. (2019, duben 30). Zákony pro lidi. Dostupné z https://www.zakonyprolidi.cz/cs/201627

Vývojová ročenka školství 2006/07-2016/17. (2019, duben 30). MŠMT. Dostupné z http://www.msmt.cz/vzdelavani/skolstvi-v-cr/statistika-skolstvi/vyvojova-rocenka-skolstvi2006-07-2016-17

Záhořáková, R., \& Kala, P. (2016). Inkluzivní vzdělávání ve vybraných evropských státech. Srovnávací studie č. 5. 366. Praha: Kancelář poslanecké sněmovny. Dostupné z file:///D:/pi-5-366\%20(2).pdf 